\title{
1
}

\section{Re-thinking Regional and Local Policies in Times of Polarisation: An Introduction}

\author{
Franziska Görmar, Thilo Lang, Erika Nagy \\ and Garri Raagmaa
}

This book takes its starting point by considering a threefold polarisation within the EU: an increasing demographic concentration in and around the bigger cities with population decline in many other regions, economic development favouring a smaller number of capital and metropolitan regions with seemingly less economic prosperity in most other regions as well as a spatially and socially uneven distribution of wealth with a growing number of people feeling neglected and favouring rightwing conservative or even extremist political positions in a number of

F. Görmar $(\bowtie) \cdot$ T. Lang

Leibniz Institute for Regional Geography, Leipzig, Germany

T. Lang

Global and European Studies Institute, University of Leipzig, Leipzig, Germany 
recent national elections. At the same time, the future of cohesion policy is again being discussed at the EU level-as happens every couple of years. And there is again the question whether cohesion policy will turn back to its original objectives of supporting the worse off regions in the European Union or whether it will follow the neoliberal course of recent years to foster competitiveness and growth.

Based on these observations, the book asks a couple of questions: What actually is meant when we are speaking about regional and cohesion policies in these times? In which ways is socio-spatial polarisation (re-)produced and how should policy respond to these processes? To what extent should we rethink current spatial policies when aiming for more just ways of development? What are the alternatives to the neoliberal mainstream?

\section{Setting the Scene: Territorial Cohesion as a Core Issue of the European Union}

Since the adoption of the Single European Act in 1985 and at least since the introduction of the Territorial Agenda of the European Union in 2007, socio-spatial cohesion has been identified as one of the core issues of the European Union. However, the goal is far from being achieved. Whereas on a national level, economic development between the different European countries converged (albeit to different degrees), it is apparent that regional inequalities within national states further increased considerably during recent years (Neufeld 2017, 27; Iammarino et al. 2017; for growing income inequalities within states see also OECD 2016). Across Europe, we are witnessing demographic growth and the

E. Nagy

Centre for Economic and Regional Studies, Hungarian Academy of

Sciences (CERS-HAS), Békéscsaba, Hungary

G. Raagmaa

University of Tartu, Tartu, Estonia 
increasing economic prosperity of a small number of big agglomerations, mainly capital cities and their surroundings. This seems to be at the expense of a growing number of rural and old industrial regions. These regions are characterised by economic and demographic stagnation or even decline (see Eurostat 2017) and the outmigration of mainly young people to the better off, mainly metropolitan areas which also attract the largest share of transnational migrants (Lang and Haunstein 2017; Dax and Fischer 2017). In a growing number of declining regions, those people who stay have an increasing feeling of being left behind (Neu 2006). Thus, the big metropolitan areas and urban agglomerations can be seen as the winners of regional polarisation, whereas rural and old industrial regions face increasing development problems. However, this is only one part of the finely grained picture which is characterised by multiple divides across Europe. Diverging economic and social developments can be witnessed on various scales "between states and regions; within regions, between core areas and peripheral areas; and between prosperous metropolitan regions and less prosperous ones" (Iammarino et al. 2017, 4) and, we would add following Kuus and Hadjimichalis in this volume, also between states or groups of states.

Since the 2004/2007 enlargement of the European Union, it has never been as apparent as it is now that cohesion policy continuously fails to achieve its ultimate goal, a balanced development of all regions in Europe which, at the end, would lead to more spatial justice. The growing focus on competitiveness and growth-deeply rooted in prevailing neoliberal logics of development—along with constraining policies of austerity even contradicts the efforts undertaken to balance uneven development in Europe (Faragó and Varró 2016; Agnello et al. 2016). Given their high importance for the economic, social and political future of the European Union (Iammarino et al. 2017), cohesion policies, the underlying power structures and their impacts have to be questioned, and new responses to regional polarisation have to be developed. Whereas there are numerous studies at different spatial levels evaluating and analysing the impact of EU regional and cohesion policies and stressing their limited success (e.g. Hadjimichalis and Hudson 2014; Piattoni and Polverari 2016; Begg 2010), this book suggests a perspective that goes beyond the analysis of current forms of policy 
and governance. It works out the political geographies of spatial injustice and seeks alternative approaches to regional and local development offering new avenues towards socio-spatial cohesion instead of furthering polarisation through focusing on global competitiveness.

Based on recent research about socio-spatial polarisation and peripheralisation processes in Europe, the book combines conceptual contributions and empirical research, both aiming to better understand these processes and linking it to current debates on territorial cohesion. We argue in favour of a political geography approach which adds to these debates the notion of "spatial justice" (e.g. Soja 2009; Harvey 1973). The growing focus on neoliberal concepts in EU and national policies such as competitiveness, innovation and growth shows us that it is very timely to discuss our understandings of "territorial cohesion" in its multiple dimensions. The normative concept of (spatial) justice allows us to question these prevailing foci, analyse the impacts of such policies and discuss arising alternatives. In this context, the book shall also contribute to the debate what kind of regional and local development approaches are fruitful to reduce current disparities and achieve progress towards a more balanced territorial development (see Pike et al. 2017b).

In the following section of this introduction, we expand, on the one hand, more on our understandings on socio-spatial polarisation and, on the other hand, spatial justice as a useful concept to overcome a narrow economic understanding of development. The third, fourth and fifth sections will introduce the three main parts of the book and their respective contributions. The third section is dedicated to the contributions of this book dealing with questions of power, since unequal power relations, especially on the European level, do play a considerable role when we are speaking about socio-spatial polarisation. In the fourth section, we shed light on the reasons why cohesion policy fails in creating a more balanced territorial development and instead reproduces socio-spatial disparities. In contrast, the fifth section of the introduction will show that, in spite of increasing regional disparities, there is some room for alternative perspectives and responses to polarisation that show potential to influence decision and policy making in the long run. Finally, we conclude with a call to rethink regional policies and find more just answers to current problems of regional development. 


\section{Spatial Justice as a Means to Overcome Polarisation}

In recent years, an understanding of polarisation as a relational, multidimensional and multi-scalar concept has emerged (see also PoSCoPP 2015; Nagy et al. 2015; Lang 2015; Kühn 2015, 2016) which includes at the same time processes of peripheralisation as well as centralisation. These processes comprise not only economic, but also infrastructural, political as well as social and discursive aspects (Kühn and Lang 2017; Kühn and Weck 2013). Leading to very different problems in fast growing, mainly metropolitan regions and shrinking and/or economically declining regions, centralisation as well as peripheralisation cause specific patterns of polarisation and affect the ultimate goal to achieve territorial cohesion or, in other words, spatial justice.

This development is closely linked to a shift in European cohesion policies during recent decades. During the 1980s and the early 1990 s, the goal was to ensure balanced growth between the regions by compensating those areas which did not profit from the integrated European economy. From the late 1990s onwards, and particularly after the 2005 relaunch of the Lisbon Agenda and the Europe 2020 strategy, the focus of the Structural Funds and Cohesion Policy changed to the promotion of faster growth and more employment, enhancing the overall competitiveness of the whole European Union (Faragó and Varró 2016, 7; see also Avdikos and Chardas 2016). This holds even truer after the 2007/2008 crisis. In its aftermath, territorial solidarity between European regions decreased further and even more attention was directed to cities and city-regions as economically and politically strong centres at the expense of the so-called "peripheries" (Faragó and Varró 2016, 8).

Although the EU as a whole seems to be back on a growth path (judged from a mainstream perspective), the newly generated wealth does not reach the people in a sufficient and territorially balanced way. In recent decades, economic growth has de-coupled from the growth of well-being and life satisfaction. This is in particular visible in Central and Eastern Europe where the focus on a competitive and innovative economy has led to further centralisation and peripheralisation and, as a result, 
to "consequential geographies of (in)justice" (Soja 2010, 1) or, in short, spatial (in)justice. The people living in places affected by this spatial injustice seem to have the increasing feeling that their places of living "don't matter" to decision-makers and urban elites (Rodríguez-Pose 2018).

In contrast to this evidence, Edward Soja (2010) defines "spatial justice" as the equitable distribution of resources, services, and access. In this sense, it can be seen as a basic human right and thus a powerful concept to overcome polarisation. It is not restricted to the economic realm but links social justice with space and can bring notions of well-being, quality of life, as well as ecological aspects in the debate on territorial cohesion (see Jones et al. in this volume).

In this sense, "spatial (in)justice" is not only the outcome of social, political, economic, ecological and cultural processes (e.g. outmigration, diminishing public services, etc.), but also a "dynamic driving force affecting these processes in significant ways" (Soja 2010, 2; for the dialectic relation between the different dimensions, see also Pike et al. $2007,1258)$. This means that the socio-communicative peripheralisation of certain regions in turn affects these processes. It could lead to a vicious cycle of decline and stigmatisation and hinder regeneration of the affected regions. Nevertheless, recent studies show that polarisation and peripheralisation have to be understood as dynamic processes that can be influenced and reversed (Lang 2015; Kühn and Lang 2017). Residents of peripheralised regions, for example, can even use negative images to get access to specific funds and support structures and open up new paths of development (Plüschke-Altof 2017). More spatial justice would be achieved if the people affected by peripheralisation processes gained greater control over the development of their region(s) and were capable of building "multiscalar institutional and informal networks of solidarity" (Hadjimichalis 2011).

Thus, the question of what kind of regional and local development is needed (Pike, Rodríguez-Pose and Tomaney 2007) is of utmost importance to finally achieve "spatial justice" or, in EU terms, territorial cohesion. Today, it seems widely acknowledged that development not only comprises an economic dimension but includes also social, ecological, political and cultural concerns leading to more complexity in decision-making. This complexity asks for a continuous debate about 
fundamental values like democracy, equity, justice, fairness, liberty and solidarity (see Hadjimichalis 2011; Soja 2010; Pike et al. 2007). It is a highly political question what regional and local development should look like as it concerns "competing visions of the 'good society" (Pike et al. 2007, 1262) which are constantly changing over time. Which of these visions prevails in the debates on regional development depends upon the institutional structures and power relations and the underlying interests of the involved actors as we will show in the chapters of the first part of the book.

\section{Socio-Spatial Polarisation in the European Union and Questions of Power}

The recent crisis and the following economic recession raised new polarities and reproduced historical fault lines within Europe, making the failure of policies that targeted stronger cohesion apparent and placing the relevance of institutional structures, practices and underlying principles at the centre of public discourses. Nevertheless, as is discussed in academic and also in policy papers, recent shifts in economic power and political conflicts are rooted in two developments which had already evolved prior to the crisis: (1) in the long-term geopolitical and geo-economic changes that questioned the dominance of the global North in controlling global flows and placed the European economy on a slow-growth track (UNCTAD 2010, 2017; Hudson 2016) and (2) in the pre-crisis inequalities within Europe that manifested in uneven patterns of capital flows, innovation and knowledge production, labour productivity and migration (Hadjimichalis 2011; Ehrlich et al. 2012). The changing position of the European economy in global flows, persisting inequalities and the recent emergence of new dimensions of unevenness (indebtedness, the spread of deep poverty, and the decay of public services resulting from austerity schemes, etc.). Moreover, the regulative deficits revealed by the crisis raised criticism towards existing institutional structures and reheated debates on institutions as agents of change also in academic circles (Pike et al. 2017a; Hadjimichalis and Hudson 2014). 
The unfolding discourse on institutions as mediators of power driving uneven development is linked to debates on retheorising power itself. The latter results in a shift from understanding power as a force and authority exercised by individuals or institutions to advance their (or particular groups') interests towards a process- and practice-focused approach and considering power as a relational effect that is at work in all social interactions. Accordingly, the multi-dimensionality of power and the variety of fields of power in which individuals are acting simultaneously gained more attention, and various modalities of power were identified from coercion, domination, authority to manipulation and seduction (Hudson 2007; Allen 2003). Relying on this broad understanding of power, scholars of various academic fields researched institutions as arenas of social struggles embedded in a multiplicity of actual social relations, being changed from inside and outside, yet preserving and reproducing historical values, norms and practices. Studies with such foci highlighted how institutional structures and practices (regulatory regimes, power geometries, policies) are shaped by and reproduce power relations and how they operate and shape everyday social practices and consequently regional and local development in a multiple and uneven way (Brenner 2009; Hudson 2007; Massey 1993).

Research on institutional practices, their socio-cultural contexts and underlying power relations advanced and deepened our knowledge on the mechanisms of polarisation processes, the emergence of new dimensions of inequalities and the differentiation at a European scale and also within European 'cores' and 'peripheries' at national and sub-national scales (Peck et al. 2012; Fischer-Tahir and Naumann 2013; Ehrlich et al. 2012; Kuus in this volume). Even though multiple institutional rearrangements (of markets, firms, NGOs, state and semi-state organisations, etc.) were identified as drivers of growing socio-spatial inequalities that all had their spatial implications, it was the reorganisation of state power that was placed at the very heart of debates, due to the centrality of state agency (as a context and as a cause) in the unfolding globalisation and the neoliberalisation processes underpinning it (Brenner 1999; Jessop 1993). The latter embraced the privatisation of public assets along with shrinking state roles in operating the systems of collective consumption, liberalisation of flows, re-regulating 
the labour-capital nexus by weakening the former's position, and the involvement of non-state organisations in governing social relations (Harvey 2007; Bockmann 2012). By driving such changes, the state emerged as an agent of uneven distribution of power and wealth through the changing regulative framework and the related institutional practices (backing financialisation, introducing austerity schemes, subordinating social policies to economic growth, shifting responsibilities to regional and local actors, etc.) and the production of narratives and new normalities for the social reality of the unfolding regime such as competitiveness, flexibility, and self-interest/reliance (Jessop and Osterlynck 2008; Hudson 2007).

The changing role of state institutions has been widely discussed in relation to their spatial reorganisation. Rescaling processes of national state power were a central issue even though scalar reorganisation was going along with other spatial transformations such as the rise of horizontal networks, new modalities of place making and changing territorialities (Brenner 1999). The debates were revolving around the state as the key agent of producing a new spatial (scalar) fix in the neoliberal regime of capitalism (Jessop 2010), the significance of architectures of institutional models driving state reorganisation (Bohle and Greskovits 2007), and the technologies of power in particular socio-spatial contexts. Yet, the growing body of scholarly work on the European context (i.e. on the emerging networked governance, changing border regimes, the growing importance of horizontal organisations in institutional learning and policy translations, rescaling processes as highly complex power games within European institutional settings—see also Kuus in this volume) and, moreover, the lessons of the recent crisis led to more complex understandings of the agency of various state institutions in uneven development (Jessop 2010; Kuus 2011; Hadjimichalis and Hudson 2014). The rise and the post-crisis revival of neoliberalism have been widely discussed as series of re-regulative processes reinforcing market rule over social relations, placing not only historical national institutions as agents in focus, but their international embedding resulting in conflicts, learning, policy experimentation and structural changes across scales. Relying on this (relational) approach, the institutional landscape driving socio-spatial polarisation has been researched and 
discussed as a highly variegated, rapidly changing set of structures and practices that embody shifting power relations from elected bodies to experts, from national institutions to international bodies and financial organisations that mediate particular national/group interests (Brenner 2009; Peck et al. 2012).

Understanding the power relations and strategies driving institutional restructuring, as well as the socio-cultural diversity and interrelatedness of institutional practices, we can reveal (and also challenge) their bias towards reproducing inequalities, and gain deeper insight into the mechanisms behind reproducing unevenness and the failures of cohesion policies in making a more just European society. By doing that, we can also enhance existing knowledge on the recent crisis and the resurgence of neoliberalism through the lens of complex, interrelated and contested European institutional settings, such as the limits of national state agency (austerity schemes imposed on national governments, public policies geared towards supporting capital accumulation instead of socio-spatial solidarity, the re-regulation of labour-capital relations, etc.) and emerging conflicts in the arenas of international organisations (Jessop 2010; Hadjimichalis and Hudson 2014).

Along these lines, the first part of this book engages with current power structures in Europe and the resulting polarisation processes. Ray Hudson and John Pickles engage in a conversation based on their seminal works on critical economic geography and regional development. They emphasise that (economic) uneven development is inherent to capitalist economies and goes hand in hand with political asymmetries and democratic deficits which manifest themselves in urban and regional policy networks favouring "the main centres of growth and affluence" and marginalising the region(s). Ray Hudson frames the European Union as "a project of and for the political and capitalist economic elites in Europe" (Hudson 2017, 139) where uneven and combined development is reproduced, "especially between the national economies and states of 'north' and 'south' and 'east'. Given this uneven nature of capitalism, they do see the risk to "rais[e] hopes that cannot be delivered", although there are some forms of capitalism that seem to be more progressive and should be encouraged and supported. Hence, they see a clear need for a political economic geography. 
In a similar vein, Costis Hadjimichalis argues that the so-called "cohesion policies" are contradictory to the priorities established in the Lisbon strategy which are "regional competitiveness", "knowledge economy" and "growth and jobs". These strategies are defined more or less solely by the economically "successful" states such as France, UK, the Benelux states, Scandinavia and particularly by Germany that aims at imposing its "ordoliberalism" on the whole European Union. The path dependency of the regions and questions of redistribution seem to be widely ignored. Instead, only a few successful star-regions are promoted as "best practices" favouring at the end only large cities at the expense of smaller ones and agricultural regions. The recent crisis has shown that these strategies do not lead to territorial cohesion but to increased spatial injustice. Furthermore, three other factors, "financialisation", "the rise of a new rentier economy", and "private and public debt", have been introduced. These factors strengthen the existing power imbalances and further the importance of metropolitan regions and the continuous marginalisation of rural peripheries.

The contribution of Hadjimichalis already indicates what Merje Kuus reveals in her chapter on state power, spatial inequality and their interrelationship with the flows and networks of (geographical) expertise. Spatial planning in Europe is becoming an increasingly transnational process that combines national, sub-national and international elements in new and ever-changing combinations. Thus, the centres and margins of policy expertise are fluid and depend not only on formal training and negotiation skills, but also on personal networks and a certain feeling for Brussels' parquet. Diplomats from the richer member states do seem to have a better stand as they tend to dispose of these networks as a result their pre-Brussels training and can build on long-standing traditions of policy expertise. Nevertheless, European and national interests cannot be isolated from each other, but are intertwined and often diffuse. Therefore, Kuus points to the difficulties in grasping these specific and at the same time diffuse patterns in scientific analysis and argues for overcoming the "methodological nationalism of our analytical toolbox" and applying a transnational lens while doing research on "the ever-shifting patterns of economic, political and symbolic peripherality". 


\section{$4 \quad$ Regional and Cohesion Policies (Re-)Producing Socio-Spatial Disparities}

The chapters in the second part of the book discuss European and regional policies and their impact on territorial cohesion within and between EU member states. Looking at the Europe 2020 strategy and its three priorities of "smart, sustainable and inclusive growth" (EC 2010), there is apparently a contradiction between the goals to enhance social and territorial cohesion on the one hand and to achieve competitiveness of each single region and Europe as a whole on the other hand. While regional policies claim to contribute to a decrease in regional disparities and to foster convergence between the regions, their application often actually intensifies regional polarisation, especially in Southern, Central and Eastern Europe (Hadjimichalis in this volume).

This spatial polarisation is not a linear process but a consequence of a combination of various factors. Governance is one of them. For instance, Central and Eastern European countries (CEEC) carried out numerous administrative and public policy reforms during the last 25 years (Swianiewicz 2010). There are several factors that made CEE governance evolve considerably differently from governance in the older member states of the European Union. Decision-making was concentrated into larger, arguably globally more competitive units. Consequently, the centralisation of power from lower administrative tiers to the national central agencies led to a (political) peripheralisation of remote regions. At the same time as Western Europe continued on a devolution track, CEEC made a sharp turn and did gradually centralise their public administration (Loewen and Raagmaa 2018; Loewen 2018). Although many academics and policy makers saw multilevel governance and several other EU policy catchwords as promising approaches to development, they do not seem to work everywhere in a similar manner (Špaček 2018). Europeanisation has never been a uniform and parallel process in all countries and European policy concepts have obtained different meanings in different countries due to distinct administrative structures, normative development models and politically 
accepted regional policy paradigms (Loewen and Raagmaa 2018). History and an administrative culture rooted in the past do matter: path-dependency is one of the factors shaping the real application of policy.

Many authors have underlined that there are no one-size-fits-all solutions (Rodríguez-Pose 2018; Iammarino et al. 2017). However, EU directives often ignore the specifics of European peripheral regions and countries. Furthermore, there are many more hidden contestations. In order to secure the usage of EU structural funds, for instance, double standards have been created: official project reports normally show good results and are in turn summarised in regional and country reports as a great success (Raagmaa and Stead 2014). For the purpose of fighting against fraud, the European Commission has strengthened accountability (at the same time preaching about simplification) resulting in even more centralisation. The related complex bureaucratic rules nurture a city-based project class and specialised firms and exclude peripheral localities that are unable to co-finance and manage such projects. That way, the gap between real needs and what policies can achieve for concrete places, thus spatial injustice, is rising.

The authors in the second part of this book criticise the strong growth-oriented focus of European cohesion and regional policies. Rhys Jones et al. argue that more attention should be paid to the academic literatures on spatial justice, human capabilities and agency that might help to spatialise the European Union's social model in more effective ways. The authors claim that applying more plural and long-term conceptions of 'development', 'well-being' and 'justice' could help to formulate regional policies that contribute more directly to the well-being and welfare of people in various parts of Europe.

The focus on economic development in cohesion policies is also apparent for Bradley Loewen and Sebastian Schulz. They have observed that despite the theoretical incompatibility between cohesion and innovation policies, the two areas often converge in a common economic strategy and further rather than diminish regional disparities. "Nevertheless, the traditional aims of Cohesion Policy to support backward regions are still seen to be important for stabilising 
socio-economic processes related to regional growth and decline, as national policy experts have been shown to recognise incompatibilities between cohesion aims and growth-through-innovation strategies". Given this fact, the authors argue that economic growth and innovation objectives should be disconnected from Cohesion Policy and refocus on its traditional domains, such as infrastructure or social investment in underdeveloped regions.

The same shift from employment and social objectives to growth and innovation is revealed by the analysis of Stefan Telle, Martin Špaček and Daniela Craciun. However, looking closer at cross-border cooperation programmes between Germany, Austria, the Czech Republic and Slovakia in the funding periods 2007-2013 and 2014-2020, they have found a significant difference in the strategic focus in old (Germany and Austria) and new (Czech Republic and Slovakia) member states with a stronger emphasis on growth and innovation in old and on employment and cohesion in new member states.

Along with the focus on growth and innovation, spatial development policies often centre on urban growth poles assuming that their successful development will create spillover effects that drive the development and economic growth of more remote regions. József Benedek, Ștefana Varvari and Cristian Marius Litan contradict this assumption in their chapter by highlighting that regional disparities in Romania (and in other countries) still increased in the current funding period despite the new growth pole strategies. These growth pole strategies are good examples for a Europeanisation process that is uncritically pushed further without taking into account national and regional characteristics.

The reproduction of socio-spatial unevenness through a very specific policy area (housing) is observed by Zsuzsanna Pósfai and Csaba Jelinek. They reveal the strongly dualistic pattern of Hungarian housing policies and trace how capital investment in housing is channelled and mediated by public policies. The authors claim that state intervention in Hungary has deepened inequalities in the housing market on various scales_-from the European to the neighbourhood scale-by promoting a middle-class oriented, depth-based property model while having very little support for social housing models. 


\section{Responses to Regional Polarisation and Alternative Perspectives}

The third part of the book will focus on strategies to cope with regional polarisation on a micro level to address the responses of individuals, firms and communities while acknowledging their limitations. The chapters in this part are based on the conviction that a dignified life, creativity and satisfaction (Iammarino et al. 2017, 3) are as important as social innovations, new economic approaches and diversification of the economic basis of the region. Scholars have increasingly argued in recent years for place-sensitive and distributed policies (Iammarino et al. 2017; Jones et al. in this volume; Küpper et al. 2017) that address all dimensions of regional development alike and do not focus solely on the economic realm. We think that every region or locality has its own specific needs and concerns, which have to be addressed (Dax and Fischer 2017; Jones et al. in this volume).

The first chapters in this book show that regional and innovation policies often further regional polarisation instead of achieving cohesion. Neoliberalism is about to hollow out the foundations of a social market economy. Within most operational programmes, the overemphasised competitiveness objective overruns distributive elements and often hinders innovative bottom-up movements. Nevertheless, such local initiatives do exist across Europe: for example, there are many quite successful social economy initiatives working in small niches towards a more just form of economic development that focuses on the well-being of individual people (Küpper et al. 2017). There are teams of local decision-makers managing to re-invent formerly stagnant places and regions by introducing new forms of local and regional governance and turning around negative images of places (Plüschke-Altof 2017; Plüschke-Altof and Grootens in this volume). There are also business cases of innovative companies operating far from the so-called hotspots of the global economy, yet still managing to be successful in global markets (Graffenberger in this volume). Thus, regional development strategies have to take into account the specific social and economic needs of regions and of regional and local actors. In many 
cases, traditional approaches to regeneration (e.g. attempting to restore growth by attracting enterprises, investment, and a skilled population) are not the best option for such regions. There are alternatives that maintain good quality of life for the populations of "peripheral" regions and a good economic environment for existing enterprises (Küpper et al. 2017, 230). One key element here could be to build communication platforms and support networking activities (see Graffenberger in this volume).

However, regional development is not only a question of empowering regional and local actors. Governments have to set the necessary frameworks to support structurally weak regions and locations (e.g. regulations for public service provision, municipal income, etc.). The responsibility for that must not be shifted to local and regional actors but is in the very competence of the state (Plüschke-Altof and Grootens in this volume; Plüschke-Altof 2017; see also the debate about regional engagement of businesses and civil society organisations in Knieling et al. 2012). It is a question of how exogenous (state-influenced) and endogenous (bottom-up) approaches can be coordinated among the different levels to bring about harmonious collaboration in all dimensions and to reduce inequalities (Jones et al. in this volume; Hudson and Pickles in this volume).

The contributions in the third part of the book seek to better understand the currently dominant social, political, economic and discursive tendencies towards polarisation and ask what we can learn from such cases and initiatives and how we can help to achieve more equal societies and more balanced spatial development.

Aura Moldovan outlines out-migration as an individual life strategy, which ultimately affects local development capacities. Using the example of North-West Romania, she shows that commuting or migration flows are, on the one hand, contributing to uneven development while being at the same time an outcome of regional inequalities. In focusing on individual life stories of people coping with the increasing disparities of the region they live in, she uncovers the issues that they are facing like missing higher education and high-income employment opportunities. Furthermore, she reveals the dependency of the researched regions on external funding to implement modern infrastructures and develop local potential.

Dependence on external funds is also visible in the case of the Hungarian and Romanian community-based initiatives that Sorin 
Cebotari and Melinda Mihály are investigating. Renewable energy projects and social and solidarity economy initiatives that use these external funds do have important strategic potential for communitycentred sustainable local development. However, the room for manoeuvre of community-based initiatives is constrained by a centralised logic of organisation, limited space for public participation and existing policy practices and administrative norms. Consequently, community-based initiatives in Hungary and Romania still fail to fully exploit the existing potential for community-centred, more sustainable local development.

Nevertheless, the example shows that social innovations do emerge in peripheral places. The same is true for business innovations. However, firms in peripheral regions are often confronted with complex situations, which limit their efforts in organising innovation activities. Martin Graffenberger presents examples from South Estonia and the Erzgebirgskreis in Germany that show how firms can overcome the limitations of their regional environments by adopting a dual strategy of strategically mobilising ties to external actors and maintaining/expanding internal capacities.

In the last chapter of the third part of the book, Bianka PlüschkeAltof and Martiene Grootens point to the limits of a purely actor-centred approach to regional development. Using the concepts of leadership and place-making as analytical lenses, they acknowledge the potential of both approaches in dealing with regional polarisation. However, they see the need to critically reflect on newly emerging problems in structurally disadvantaged rural areas, such as the idealisation and responsibilisation of local leadership. Local response strategies do have certain limits and practitioners and researchers have to reflect upon the complexity of regional and local development and regional polarisation.

\section{Time to Re-think Spatial Policies}

Currently, regional policies are widely discussed at the EU level with regard to a most likely more restricted budget due to the exit of the United Kingdom. The 7th Cohesion Report (EC 2017) shows that 
cohesion policies do have a considerable impact on so-called "lagging" regions in Eastern and Southern Europe where GDP growth is the highest in Europe. However, this impact is foremost an economic one. At the same time, the EU Social Progress and the European Quality of Government Indices have the lowest scores in these regions (EC 2017). Thus, economic growth does not seem to go hand in hand with political and social satisfaction, public participation or individual wellbeing. This fact underlines our plea to re-think spatial policies considering alternative approaches going beyond purely economic growth.

This book describes the current power structures and prevailing policy paradigms and argues for a critical re-consideration of the effects of the last two programming periods of European funding. It seems to us that global, European and national policies are slowly, but increasingly aware of the challenges we are facing. For instance, the United Nations address with their Sustainable Development Goals (UN 2015), besides inclusive and sustainable economic growth and many others, explicitly the reduction of inequalities and poverty as well as the promotion of well-being (in a similar vein, see OECD 2016). In Europe, policy makers do acknowledge existing inequalities although mostly in the economic realm and with different propositions for their solution. For instance, the migration of well-qualified people from Eastern to Western European countries and from rural to urban areas and its negative consequences on regional and local development (such as the loss of social capacities) is widely recognised (EC 2017).

Up to now, politics and regional development policies tend to focus on so-called best practice examples neglecting the wider context in which these are embedded (see Hadjimichalis in this volume). It is often assumed that these examples can be transferred to any other region in a top-down manner without taking into account the specific institutional arrangements, decision-making structures and local actors in the regions. Actors in the economic and political centres define the (European) priorities for development and choose the corresponding best practices from their perspective. In contrast, we are calling on people in every region and locality and on society as a whole to think about which priorities based on which values should be set (Pike et al. 2007, 1255). 
Spatially just policies should give, on the one hand, greater control to those people who are affected by polarisation processes, giving them the voice, the power and the capabilities to define their own priorities and develop place-based approaches to overcome peripheralisation (see Jones et al. in this volume). On the other hand, there are structural challenges in many peripheralised and marginalised places that cannot be neglected by the centres. Governmental decision-makers have to be aware of multiple peripheralisation, take over the responsibility and adjust existing policy frameworks towards a cooperative and participatory democracy (Piattoni and Polverari 2016) based on the values of solidarity and cohesion (see Plüschke-Altof and Grootens in this volume). Policies have to focus on people enhancing their opportunities where they live (Rodríguez-Pose 2018) and providing them with a solid and stable policy framework and appropriate social and physical infrastructures. This book aims to be a resource for all scholars in academia and practice working towards these issues.

\section{References}

Agnello, Luca, Giorgio Fazio, and Ricardo M. Sousa. 2016. "National Fiscal Consolidations and Regional Inequality in Europe." Cambridge Journal of Regions, Economy and Society 9: 59-80. https://doi.org/10.1093/cjres/ rsv033.

Allen, John. 2003. Lost Geographies of Power. Oxford: Blackwell.

Avdikos, Vasilis, and Anastassios Chardas. 2016. "European Union Cohesion Policy Post 2014: More (Place-Based and Conditional) Growth—Less Redistribution and Cohesion." Territory, Politics, Governance 4 (1): 97-117. https://doi.org/10.1080/21622671.2014.992460.

Begg, Iain. 2010. "Cohesion or Confusion: A Policy Searching for Objectives." Journal of European Integration 32 (1): 77-96. https://doi. org/10.1080/07036330903375115.

Bockmann, Johanna. 2012. "The Political Projects of Neoliberalism." Social Anthropology 20 (3): 310-17. https://doi.org/10.1111/j.1469-8676.2012. 00208.x. 
Bohle, Dorothee, and Béla Greskovits. 2007. "The State, Internationalization, and Capitalist Diversity in Eastern Europe." Competition and Change 11 (2): 89-115. https://doi.org/10.1179/102452907X181929.

Brenner, Neil. 1999. "Globalisation as Reterritorialisation: The Re-scaling of Urban Governance in the European Union." Urban Studies 36 (3): 431-51. https://doi.org/10.1080/0042098993466.

Brenner, Neil. 2009. "Open Questions on State Rescaling." Cambridge Journal of Regions, Economy and Society 2 (1): 123-39. https://doi.org/10.1093/ cjres/rsp002

Dax, Thomas, and Michael Fischer. 2017. "An Alternative Policy Approach to Rural Development in Regions Facing Population Decline." European Planning Studies 26 (2): 297-315. https://doi.org/10.1080/09654313.201 7.1361596.

EC-European Commission. 2010. "Europe 2020. A European Strategy for Smart, Sustainable and Inclusive Growth.” Brussels. http://ec.europa.eu/ eu2020/pdf/COMPLET\%20EN\%20BARROSO\%20\%20\%20007\%20 -\%20Europe\%202020\%20-\%20EN\%20version.pdf.

EC-European Commission. 2017. "My Region, My Europe, Our Future." Seventh Report on Economic, Social and Territorial Cohesion. Luxembourg: Publications Office of the European Union. http://ec.europa. eu/regional_policy/sources/docoffic/official/reports/cohesion $7 / 7 \mathrm{cr}$.pdf.

Ehrlich, Kornelia, Agnes Kriszan, and Thilo Lang. 2012. "Urban Development in Central and Eastern Europe-Between Peripheralization and Centralization?” DisP_The Planning Review 48 (2): 77-92. https://doi.org/ 10.1080/02513625.2012.721611.

Eurostat. 2017. "Eurostat Regional Yearbook." Subchapter on Population Statistics at Regional Level. http://ec.europa.eu/eurostat/statistics-explained/ index.php/Population_statistics_at_regional_level\#Population_change. Accessed 21 February 2018.

Faragó, László, and Krisztina Varró. 2016. "Shifts in EU Cohesion Policy and Processes of Peripheralization: A View from Central Eastern Europe." European Spatial Research and Policy 23 (1): 5-19. https://doi.org/10.1515/ esrp-2016-0001.

Fischer-Tahir, Andrea, and Matthias Naumann, eds. 2013. Peripheralization: The Making of Spatial Dependencies and Social Injustice. Wiesbaden: Springer.

Hadjimichalis, Costis. 2011. "Uneven Geographical Development and SocioSpatial Justice and Solidarity: European Regions After the 2009 Financial 
Crisis." European Urban and Regional Studies 18 (3): 254-74. https://doi. org/10.1177/0969776411404873.

Hadjimichalis, Costis, and Ray Hudson. 2014. "Contemporary Crisis Across Europe and the Crisis of Regional Development Theories." Regional Studies 48 (1): 208-18. https://doi.org/10.1080/00343404.2013.834044.

Harvey, David. 1973. Social Justice and the City. Oxford: Blackwell.

Harvey, David. 2007. "Neoliberalism as Creative Destruction." The Annals of the American Academy of Political and Social Science 610 (1): 22-44. https:// doi.org/10.1177/0002716206296780.

Hudson, Ray. 2007. "Regions and Regional Uneven Development Forever? Some Reflective Comments Upon Theory and Practice." Regional Studies 41 (9): 1149-60. https://doi.org/10.1080/00343400701291617.

Hudson, Ray. 2016. "Rising Powers and the Drivers of Uneven Global Development." Area Development and Policy 1 (3): 279-94. https://doi.org /10.1080/23792949.2016.1227271.

Hudson, Ray. 2017. "Facing Forwards, Looking Backwards: Coming to Terms with Continuing Uneven Development in Europe." European Urban and Regional Studies 24 (2): 138-41. https://doi.org/10.1177/ 0969776416689230.

Iammarino, Simona, Andrés Rodríguez-Pose, and Michael Storper. 2017. "Why Regional Development Matters for Europe's Economic Future." Working Paper 07/2017, Publications Office of the European Union, Luxembourg. http://ec.europe.eu/regional_policy/sources/docgener/work/ 201707_regional_development_matters.pdf.

Jessop, Bob. 1993. "Towards a Schumpeterian Workfare State? Preliminary Remarks on Post-Fordist Political Economy." Studies in Political Economy 40 (1): 7-39. https://doi.org/10.1080/19187033.1993.11675409.

Jessop, Bob. 2010. "The 'Return' of the National State in the Current Crisis of the World Market." Capital \& Class 34 (1): 38-43. https://doi. org/10.1177/0309816809353480.

Jessop, Bob, and Stijn Oosterlynck. 2008. "Cultural Political Economy: On Making the Cultural Turn Without Falling Into Soft Economic Sociology." Geoforum 39 (3): 1155-69. https://doi.org/10.1016/j.geoforum.2006.12.008. Knieling, Jörg, Frank Othengrafen, and Tobias Preising. 2012. "Privatisierung von Stadt- und Regionalentwicklung: Gesellschaftlicher Nutzen oder Verwirklichung von Unternehmenszielen? Corporate Spatial Responsibility 'Oder, Corporate Spatial Strategy'?' Raumforschung und Raumordnung 70 (5): 451-64. https://doi.org/10.1007/s13147-012-0188-5. 
Kühn, Manfred. 2015. "Peripheralization: Theoretical Concepts Explaining Socio-Spatial Inequalities." European Planning Studies 23 (2): 367-78. https://doi.org/10.1080/09654313.2013.862518.

Kühn, Manfred. 2016. Peripherisierung und Stadt: Städtische Planungspolitiken gegen den Abstieg. Urban Studies. Bielefeld: Transcript.

Kühn, Manfred, and Sabine Weck. 2013. "Peripherisierung-Ein Erklärungsansatz zur Entstehung von Peripherien.” In Peripherisierung, Stigmatisierung, Abhängigkeit? Deutsche Mittelstädte und ihr Umgang mit Peripherisierungsprozessen, edited by Matthias Bernt and Heike Liebmann, 24-46. Wiesbaden: Springer VS.

Kühn, Manfred, and Thilo Lang. 2017. "Metropolisierung und Peripherisierung in Europa-Eine Einführung." Europa Regional 4/2015 (2017): 2-14. http://nbn-resolving.de/urn:nbn:de:0168-ssoar-53587-3.

Küpper, Patrick, Stefan Kundolf, Tobias Mettenberger, and Gesine Tuitjer. 2017. "Rural Regeneration Strategies for Declining Regions: Trade-Off Between Novelty and Practicability." European Planning Studies 26 (2): 229-55. https://doi.org/10.1080/09654313.2017.1361583.

Kuus, Merje. 2011. "Whose Regional Expertise? Political Geographies of Knowledge in the European Union." European Urban and Regional Studies 18 (3): 275-88. https://doi.org/10.1177/0969776411406034.

Lang, Thilo. 2015. "Socio-Economic and Political Responses to Regional Polarisation and Socio-Spatial Peripheralisation in Central and Eastern Europe: A Research Agenda." Hungarian Geographical Bulletin 64 (3): 17185. https://doi.org/10.15201/hungeobull.64.3.2.

Lang, Thilo, and Stefan Haunstein. 2017. "Wachsende Regionale Polarisierung in Europa.” Nationalatlas Aktuell 11 (8). http://aktuell.nationalatlas.de/ wp-content/uploads/17_08_Polarisierung_in_Europa.pdf.

Loewen, Bradley. 2018. "From Decentralization to Re-centralization: Tendencies of Regional Policy and Inequalities in Central and Eastern Europe." Administrative Culture 18 (2): 103-26. http://halduskultuur.eu/ journal/index.php/HKAC/article/view/162/157.

Loewen, Bradley, and Garri Raagmaa. 2018. "Introduction to the Special Issue: Territoriality and Governance in the Globalizing European Eastern Peripheries." Administrative Culture 18 (2), 89-101. http://halduskultuur. eu/journal/index.php/HKAC/article/view/175/156.

Massey, Doreen. 1993. "Questions of locality." Geography 78 (2): 142-49. Nagy, Erika, Judit Timár, Gábor Nagy, and Gábor Velkey. 2015. "The Everyday Practices of the Reproduction of Peripherality and Marginality in Hungary." 


\section{In Understanding Geographies of Polarization and Peripheralization:} Perspectives from Central and Eastern Europe and Beyond, edited by Thilo Lang, Sebastian Henn, Wladimir Sgibnev, and Kornelia Ehrlich, 135-55. New Geographies of Europe. Basingstoke: Palgrave Macmillan.

Neu, Claudia. 2006. "Territoriale Ungleichheit-Eine Erkundung." Aus Politik und Zeitgeschichte 37: 8-15. http://www.bpb.de/apuz/29546/ territoriale-ungleichheit-eine-erkundung? $\mathrm{p}=$ all.

Neufeld, Markus. 2017. "Eine Frage des Maßstabs? Zum Verhältnis von Kohäsion und Polarisierung in Europa.” Europa Regional 23.2015 (2017), 4: 15-29. http://nbn-resolving.de/urn:nbn:de:0168-ssoar-53592-0.

OECD. 2016. OECD Regions at a Glance 2016. Paris: OECD Publishing. http://dx.doi.org/10.1787/reg_glance-2016-en. Accessed 18 April 2018.

Peck, Jamie, Nik Theodore, and Neil Brenner. 2012. "Neoliberalism Resurgent? Market Rule After the Great Recession." South Atlantic Quarterly 111 (2): 265-88. https://doi.org/10.1215/00382876-1548212.

Piattoni, Simona, and Laura Polverari (eds.). 2016. Handbook on Cohesion Policy in the EU. Cheltenham: Edward Elgar.

Pike, Andy, Andrés Rodríguez-Pose, and John Tomaney. 2007. "What Kind of Local and Regional Development and for Whom?” Regional Studies 41 (9): 1253-69. https://doi.org/10.1080/00343400701543355.

Pike, Andy, Andrés Rodríguez-Pose, and John Tomaney. 2017a. Local and Regional Development. 2nd ed. London: Routledge.

Pike, Andy, Andrés Rodríguez-Pose, and John Tomaney. 2017b. "Shifting Horizons in Local and Regional Development." Regional Studies 51 (1): 46-57. https://doi.org/10.1080/00343404.2016.1158802.

Plüschke-Altof, Bianka. 2017. Images of the Periphery Impeding Rural Development? Discursive Peripheralization of Rural Areas in Post-socialist Estonia. Dissertation. Tartu University Press, Tartu.

PoSCoPP-Research Group Production of Space in the Context of Polarization and Peripheralization. 2015. "Understanding New Geographies of Central and Eastern Europe." In Understanding Geographies of Polarization and Peripheralization: Perspectives from Central and Eastern Europe and Beyond, edited by Thilo Lang, Sebastian Henn, Wladimir Sgibnev, and Kornelia Ehrlich, 1-21. New Geographies of Europe. Basingstoke: Palgrave Macmillan.

Raagmaa, Garri, and Dominic Stead. 2014. "Spatial Planning in the Baltic States: Impacts of European Policies." European Planning Studies 22 (4): 671-79. http://dx.doi.org/10.1080/09654313.2013.772730. 
Rodríguez-Pose, Andres. 2018. "The Revenge of the Places That Don't Matter (And What to Do About It)." Cambridge Journal of Regions, Economy and Society 11 (1): 189-209. https://doi.org/10.1093/cjres/rsx024.

Soja, Edward. 2009. "The City and Spatial Justice." Justice Spatiale/Spatial Justice 1 (September): 1-5. http://www.jssj.org/article/la-ville-et-la-justicespatiale/. Accessed 13 March 2018.

Soja, Edward. 2010. Seeking Spatial Justice. Minneapolis: University of Minnesota Press.

Špaček, Martin. 2018. "Multilevel Cross-Border Governance in the CzechSaxon Borderland: Working Together or in Parallel?” Administrative Culture 18 (2): 175-202. http://halduskultuur.eu/journal/index.php/HKAC/ article/view/161/160.

Swianiewicz, Paweł. 2010. "If Territorial Fragmentation Is a Problem, Is Amalgamation a Solution? An East European Perspective." Local Government Studies 36 (2): 183-203. https://doi.org/10.1080/ 03003930903560547.

UN_United Nations. 2015. "Sustainable Development Goals." https://www. un.org/sustainabledevelopment/sustainable-development-goals/.

UNCTAD_United Nations Conference on Trade and Development. 2010. "World Investment Report 2010. Investing in a Low-Carbon Economy." New York: United Nations. http://unctad.org/en/Docs/wir2010_en.pdf. UNCTAD_United Nations Conference on Trade and Development. 2017. "World Investment Report 2017. Investment and the Digital Economy." New York: United Nations. 
Open Access This chapter is licensed under the terms of the Creative Commons Attribution 4.0 International License (http://creativecommons. org/licenses/by/4.0/), which permits use, sharing, adaptation, distribution and reproduction in any medium or format, as long as you give appropriate credit to the original author(s) and the source, provide a link to the Creative Commons license and indicate if changes were made.

The images or other third party material in this chapter are included in the chapter's Creative Commons license, unless indicated otherwise in a credit line to the material. If material is not included in the chapter's Creative Commons license and your intended use is not permitted by statutory regulation or exceeds the permitted use, you will need to obtain permission directly from the copyright holder.

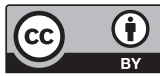

